\title{
Potensi Beberapa Tumbuhan Buah Lokal di Kawasan Agrowisata Lubuk Beringin Kabupaten Bungo
}

\author{
Akhyarnis Febrialdi \\ Agroteknologi Fakultas Pertanian Universitas Muara Bungo \\ febrialdi81@gmail.com
}

\begin{abstract}
Abstrak
Lubuk beringin merupakan salah satu destinasi agrowista populer di Kabupaten Bungo. Memiliki sumberdaya alam wisata serta menyimpan kekayaan sumberdaya genetik tanaman buah lokal yang beragam. Beberapa tumbuhan buah tersebar disekitar hutan pada kawasan lubuk beringin. Dengan metode eksplorasi dan pengumpulan informasi dari masyarakat terdapat 13 Family dan 16 Jenis tumbuhan buah lokal dengan status terbanyak tumbuh liar.
\end{abstract}

Kata Kunci: Tumbuhan Buah Lokal, Agrowisata, Lubuk Beringin

\section{PENDAHULUAN}

Lebih dari $17 \%$ keseluruhan makhluk hidup terdapat di Indonesia (Muchtadi, 2006). Indonesia menjadi satu dari dua belas Pusat Keanekaragaman Hayati Vavilov (1951). Khusus untuk pertanian merupakan kawasan terluas di Pusat Indomalaya (sutrisno dan silitonga, 2003). Riai dkk (1992) mengungkapkan di Indonesia lebih 28.000 jenis tumbuhan dan diantaranya 400 jenis buah-buahan yang dapat dikonsumsi dan sangat bermanfaat sebagai sumber keragaman genetik bagi program pemuliaan tanaman.

Setidaknya saat ini terdapat 30.000 jenis tumbuhan berbunga dimana sebagian besar tumbuh liar di hutan diberbagai kawasan Indonesia. Baru sekitar 4.000 jenis saat ini yang diketahui dan dimanfaatkan langsung oleh penduduk, sekitar seperempatnya dibudidayakan bahkan kurang dari 10 persennya (Dodo, 2007). Oleh karena itu masih banyak jenis tumbuhan yang belum diketahui, khususnya kelompok tanaman buah lokal Indonesia yang semakin jarang ditemui.

Buah lokal Indonesia merupakan jenis buah lokal yang hidup salami dan berasal dari kawasan Indonesia (Uji, 2007). Jenis buah adalah buah-buahan dari tumbuhan tahunan yang dapat dimakan (edible fruit) dapat berupa buah masak ataupun mentah (Prosea, 1991). Jurnal Pusat Konservasi Tumbuhan Kebun Raya-LIPI menyampaikan bahwa terdapat 226 jenis tumbuhan buah-buahan asli Indonesia yang dapat dimakan dan sebagian besar tumbuh liar di hutan (184 jenis), hanya sebagian kecil saja yang telah dibudidayakan (62 jenis) dan 18 jenis diantaranya merupakan jenis endemik (Dodo, 2015).

Sumber daya hayati yang melimpah di Indonesia ini sangat perlu semaksimal mungkin dimanfaatkan untuk memenuhi kebutuhan pangan khususnya buah-buahan. Tercatat sedikitnya ada 4 marga dari 4 suku buah-buahan Indonesia asli sangat bernilai ekonomi cukup tinggi serta mempunyai keanekaragaman jenis yang tinggi. Masingmasing merupakan suku Anacardiaceae (marga Mangifera), Clusiaceae (marga Garcinia), Sapindaceae (marga Nephelium) dan suku Bombacaceae (marga Durio). Empat jenis komoditas buah-buahan dari keempat marga tersebut telah ditetapkan sebagai "buah-buahan unggulan nasional", masing-masing adalah buah mangga, manggis, rambutan dan durian (Winarno, 2000).

Kabupatan Bungo salah satu kabupaten di propinsi Jambi yang memiliki perkebunan sawit, karet yang sangat luas. Lubuk Beringin adalah desa yang kini menjadi destinasi agrowisata populer di 
Kabupaten Bungo yang menawarkan alam yang asri, serta terdapat Sungai Batang Buat dengan air jernih dan segar, hutan disekitarnya banyak menghasilkan buahbuahan seperti durian, rambutan, rambei, cempedak.

\section{Metode}

Jenis penelitian ini adalah kualitatif dengan metode deskriptif dilanjutkan dengan penelitian pengembangan. Pengumpulan sumber daya tanaman buah lokal dilaksanakan pada bulan Februari sampai April 2020. Lokasi yang dipilih merupakan kawasan yang berada di sekitar hutan wisata alam Lubuk Beringin dan pemukiman penduduk dusun Lubuk beringin Kecamatan Bathin III Ulu Kabupaten Bungo. Kegiatan eksplorasi merujuk pada metode eksplorasi (Rugayah et al. 2004), yaitu menelusuri kawasan hutan dan permukiman penduduk.

Informasi pemanfaatan tanaman buah lokal dilakukan dengan mewawancarai penduduk setempat yang dipilih berdasarkan pertimbangan tertentu, salah satunya kepemilikan buah lokal serta tokoh masyarakat yang mengetahui keberadaan sumber daya tanaman buah lokal di hutan tersebut. Informasi juga dikumpulkan dari data statsitik yang dipublikasikan dalam Bungo dalam angka 2020.

\section{Hasil dan Pembahasan}

\section{Potensi Tumbuhan Buah Lokal}

Hutan memberi beragam manfaat bagi kehidupan manusia, baik secara langsung maupun tidak langsung. Menurut Gardner dan Engleman (1999), secara langsung, hutan dapat menghasilkan kayu industri, kayu bakar, dan hasil hutan non kayu; menyediakan lahan untuk permukiman dan pertanian; dan lain sebagainya. Sementara itu secara tidak langsung, hutan dapat mengatur tata air di alam (hidrologi), menyimpan karbon, melestarikan keanekaragaman hayati dan habitat, pasokan oksigen, dan sebagai obyek pariwisata.
Hutan mempunyai peranan yang sangat berarti bagi masyarakat di desa sekitar desa Lubuk Beringin. Hutan menyediakan lahan yang diperlukan untuk perluasan areal pertanian. Hutan juga menyediakan hasilhasil hutan baik berupa kayu maupun nonkayu, untuk memenuhi kebutuhan sendiri sehari-hari ataupun untuk dijual. Dalam pengambilan hasil hutan oleh masyarakat ada beberapa hasil hutan yang dianggap sebagai hasil hutan utama dan hasil hutan sampingan. Hasil hutan utama adalah hasil hutan yang mempunyai harga pasar yang cukup baik, permintaan pasar tinggi dan cukup banyak tersedia di hutan. Komoditi ini diambil secara sengaja dengan waktu, persiapan dan perlengkapan yang dibawa secara khusus. Komoditi semacam ini adalah kayu balok, rotan, burung, madu, dan ikan sungai. Sedangkan hasil hutan sampingan adalah hasil hutan yang biasanya diperoleh pada saat pengambilan hasil hutan utama, atau yang proses untuk mendapatkannya tidak membutuhkan waktu dan perlengkapan yang khusus. Hasil sampingan contohnya adalah gaharu, getah jernang, getah balam, dan buah-buahan.

Beberapa hasil hutan yang terdapat di hutan lubuk beringin adalah buah-buah liar semacam takokak (Solanum torvum) dan kepayang (Pangium edule), Minyak kepayang merupakan bahan makanan yang disukai, walaupun sekarang jarang orang yang membuatnya. Juga beberapa macam bahan ramuan obat dan rempah seperti sirih (Piperbetle), gambir (Uncaria gambir), asam kandis (Garcinia xanthochymus.) dan damar. Sebagaian jenis buah-buahan Durian (Durio zibethinus), langsat (Lansium domesticum) dan bedaro (Nephelium sp.), nangka dan cempedak (Artocarpus spp.), mangga (Garcinia mangostana), kasai (Pometia sp.), rukam (Flacourtia rukam), rambutan (Nephelium lappaceum), jambu (Syzgium) dan pisang (Musa). Pada Tabel 1 disampaikan beberapa buah local dengan sebutan local serta status tumbuhnya. Beberapa tumbuhan buah sudah dbudidayakan, namun masih banyak yang tumbuah liar di hutan. 
Tabel 1. Tabel Tumbuhan Buah Lokal

\begin{tabular}{|c|c|c|c|}
\hline Family & Jenis & Nama Lokal & Status \\
\hline Achariaceae & Pangium edule & Kepayang & Liar \\
\hline Clusiaceae & Garcinia xanthochymus & Asam kandis & Liar \\
\hline Malvaceae & Durio zibethinus & Durian & Liar \\
\hline Meliaceae & Lansium domesticum & Langsat & Liar \\
\hline Sapindaceae & Dimocarpus malayensis & Bedaro & Liar \\
\hline Anancardiaceae & Mangifera indica & Mangga & Liar/Budidaya \\
\hline Moraceae & Artocarpus integer & Cempedak & Liar \\
\hline Sapindaceae & Pometia Pinnata & Kasai & Liar \\
\hline Salicaeae & Flacourtia rukam & Rukam & Liar \\
\hline Sapindaceae & Nephelium lappaceum & Rambutan & Liar \\
\hline Myrtaceae & Syzgium & Jambu & Liar/Budidaya \\
\hline Musaceae & Musa & Pisang & Liar/Budiday \\
\hline Phyllanthaceae & Baccaurea Motleyana & Rambei & Liar \\
\hline Solanaceae & Solanum torvum & Rimbang & Liar/Budiday \\
\hline Fabaceae & Parkia Speciosa & Petai & Liar \\
\hline Fabaceae & Archidendron Pauciflorum & Jering & Liar \\
\hline
\end{tabular}

Banyak Tumbuhan Buah yang dimanfaatkan oleh masyarakat langsung serta dijual di pasar terdekat. Hala ini menjadi nilai tambah eknomi bagi masyarakat sekitar.

\section{DAFTAR PUSTAKA}

Amrullah, 2011. Upaya Pelestarian Plasma Nutfah Berbagai Komoditas Propinsi Aceh. Sutraco Seed. Aceh.

\section{Kesimpulan}

Hasil ekplorasi tanaman buah local di sekitar hutan lubuk beringin terdapat 13 Family dan 16 Jenis tumbuhan buah lokal dengan status terbanyak tumbuh liar. Potensi ini dapat dimanfaatkan baik secara langsung dan sangat bernilai secara ekonomi

Febrialdi, Akhyarnis. (2016). Tanaman Obat. 10.13140/RG.2.2.20928.23046.

Febrialdi, A., \& Subagiono, S. (2017). Beberapa Tanaman Obat Yang Digunakan Masyarakat Desa Sungai Telang 
Kecamatan Bathin Iii Ulu Kabupaten

Bungo. Jurnal Sains Agro, 1(1).

BalaiKonservasi Sumber Daya Alam. 2006, Laporan PelaksanaanKegiatan

SosialisasiTNBD dan manfaatnya kepada masyarakat sekitar TNBD Jambi

Belajar dari Bungo, 2008 Mengelola Sumberdaya Alam di Era Desentralisasi

Bungo dalam angka 2012

Dewi, S., Ekadinata, A., Nugroho, D. K. 2008. Land cover changes in different forest transition stages in Indonesia: East Kalimantan, Jambi and Lampung. World Agroforestry Centre. (ICRAF). Bogor

Febrialdi, A., \& Subagiono, S. (2017). Beberapa Tanaman Obat Yang Digunakan Masyarakat Desa Sungai Telang Kecamatan Bathin Iii Ulu Kabupaten Bungo. Jurnal Sains Agro, 1(1).

Gardner, T., Engelman, R. 1999. Forest Futures: Population, Consumption and Wood Resources. Population Action International. Washington

ICDP-TNKS Komponen D. 2002. Laporan Akhir Monitoring dan Evaluasi PPWK.

ICDP-TNKS Komponen D.

Kusumo SM, Hasanah S, Moeljopawiro M, Thohari, Subandriyo A, Hard jamulia A, Nurhadi, Kasim H. 2002. Pedoman pembentukankomisi daerah dan pengelolaan plasma nutfah. Komisi Nasional Plasma Nutfah, Bogor. Badan Penelitian dan Pengembangan Pertanian. Jakarta.

Luyet, B.J. 1937. The vitrification of organic colloids and of protoplasms. Biodinamica 1:1-14.

Muchtadi, t. R. 2006. Kebijakan RISTEK dalam Meningkatkan Kegiatan Penelitian Keanekaragaman Hayati. Lokakarya Nasional "Keanekaragaman Hayati di Ujung Tanduk". Organisasi Profesi Ilmiah dan LIPI. Jakarta, 18-19 Desember 2006.

Purnomo S, Edison, Suharto, Marsono. 2001. Naskah pelepasan varietas unggul baru nasional Durian TAKADA-01 dan
JEBUS PETALING-06. Balai Penelitian Tanaman Buah, IP2TP Bangka dan Badan Benih Nasional. Hal 38.

Plasma Nutfah Tanaman:Peluang Pemanfaatannya di Indonesia 2007

Peraturan Menteri Pertanian Nomor 37 Tahun 2011

Profil permukiman transmingrasi rantau pandan x Kabupaten Bungo, Direktorat jenderal pembinaan Pengembangan masyarakat dan kawasan transmigrasi kementrian tenaga kerja dan transmigrasi

Reed, B.M. 2002. Implementing cryopreservation for longterm germplasm preservation in vegetatively propagated species. Biotechnology in Agriculture and Forestry, Cryopreservation of Plant Germplasm II(50):23-33.

Rifai, m. A., rugayah, dan e.a. Widjaja. 1992. Floribunda. Tiga Puluh Tumbuhan Obat Langka Indonesia. Penggalang Taksonomi Tumbuhan Indonesia. Sisipan Floribunda 2: 1- 28.

Semuel Leunufna Jurnal AgroBiogen 3(2):80-88 Kriopreservasi untuk Konservasi

Sutrisno dan t.s. Silitonga. 2003. Pengelolaan Plasma Nutfah Nabati (Tumbuhan dan Tanaman) sebagai Aset dalam Pemenuhan Kebutuhan Manusia. Apresiasi Pengelolaan Plasma Nutfah. Bogor, 23-27 Juni 2003.

Takagi, H. 2000. Recent development in cryopreservation of shoot apices of tropical species. Cryopreservation of Tropical Plant Germplasm, Current Progress and Application. JIRCAS International Agriculture Series 8:330333.

Vavilov, n.i. 1951. The Origin, Variation, Immunity and Breeding of Cultivated Plants. (Trans. By. K. STARR CHESTER, Chronica Bot. 13 (1/6). 364 pp.

Dodo. 2015. Keanekaragaman dan Konservasi Tumbuhan Langka Indonesia. Warta Kebun Raya.

13(2):37-42

Uji, T. 2007. Review. Keanekaragaman Jenis Buah-Buahan Asli Indonesia dan Potensinya. Biodiversitas 8(2):157-167. 
Febrialdi, A. (2018). Profil Beberapa Tanaman Obat di Hutan Sungai Telang Kabupaten Bungo. Jurnal Sains Agro, 3(1).

Rugayah, Retnowati, A., Windadri, F.I. \& Hidayat, A. (2004) Pengumpulan data taksonomi. Dalam: Rugayah, Widjaja, E.A. \& Praptiwi (editor) Pedo-man Pengumpulan Data Keanekaragaman Flora. Bogor, Pusat Penelitian Biologi, LIPI, hlm. 5-42. 